\title{
Part VIII
}

\section{Bibliography}

\section{ADMINISTRATIVE LAW AND PROCEDURE}

\section{Robert I. Conn}

The compiling of a bibliography of Administrative Law and Procedure presents numerous problems. The topic is one difficult to delineate and the selection of the most useful order and manner of citation presents a perplexing problem. An explanatory note is therefore necessary.

The attempt has been to include in this bibliography a reference to every significant piece of legal writing on or relevant to the subject of California Admimistrative Law and Procedure. Though most of the materials included are to be found in California legal periodicals, other materials have been included where particularly relevant. Though research was not limited to any particular group of publications, special attention was given in compiling the bibliography to the following legal periodicals: the California Law Review, the California State Bar Journal, the Hastings Law Journal and Intramural Law Review, the Southern California Law Review, the Stanford Law Review, and the U.C.L.A. Law Review and Intramural Law Review.

The bibliography is arranged under broad subject headings, with subheadings where appropriate. Within this general arrangement the items in the bibliography are cited in chronological order, latest first, where no other order of citation seemed more appropriate. Wherever an article or book is of particular importance, however, it is cited first regardless of date. The titles of books and professional articles and the names of their authors are given in full. Student work is indicated by a brief descriptive phrase and citation only, the name of the author being omitted. Articles and notes are segregated only in the largest subject headings.

\section{Texts and References}

GENERAL

The leading text is Kuchuan, Carl. Camifornia Administrative Law and Procedure (1953). Reviewed by John Clarkson, 41 CarfF. L. Rev. 766 (1953); Victor S. Netterville, 27 So. CaIIF. L. Rev. 116 (1953) ; Max Utt, 29 CaLIF. S.B.J. 149 (1954).

Davis, K. C. Administrative Law (1951).

Davis, K. C. Cases on Administrattve Law (1951).

Gexthorr, Watter and Byse, Clark. Administrative Law Cases and Comments (1954).

Heady, Ferrax. Administrative Procedure Legislation in the States (1952).

Newman, Frank C. Syllabus on California Administrative Law (with accompanying bibhography). (Published by the University of California Extension 1955).

Wrtkin, B. E. Summary of California Law (6th ed. 1946 and 1950 Supp.).

Witkin, B. E. California Procedure. (3 volumes) (1954).

Judiciat Council of Calmornia, 10tr Brennial Report. (Dec. 31, 1944).

Californta Admomistrattve Procedure Act. (Published by the Division of Administrative Procedure 1955). 
Cartfornta Adninistrative Code, supplemented by the Catifornta Administrative Rrgister. These are official state publications and contain the rules of state agencies filed with the Secretary of State pursuant to the California Administrative Procedure Act (Cal. Govt. Code $\$ 11370$ et seq.). Title 1 lists in alphabetical order the agencies whose rules are included. The code consists of 23 titles. Cf. Conrey, Lucille. From the Cradle to the Grave, or Title 1 to Title 23, California Administrative Code. 25 CaIIF. S.B.J. 503 (1950).

Code of Ethics for Administrative Officials. Issued by Governor Warren, July 16, 1948. 23 CaIr. S.B.J. 181 (1948).

First, Second, Third, Fourth and Fifth Biennial Reports, Division of Admonistrative Procedure (1947, 1949, 1951, 1953 \& 1955).

2 CaI. Jur.2d (pp. 8-414, and pocket supp.); 1 McKTnney's NEw CaIIF. Dig. (pp. 533-42, and pocket supp.); 4 WEST's CALIF. Dig. (pp. 281-373, and pocket supp.).

ROSTER (State, County, City and Township Officials of the State of California; also Federal Officials for California) $(1955,1956)$.

Tomprins, Dorotery C. State Governament and Administration-A Bibliography. (Bureau of Public Administration, University of California 1954).

Chronorogical List of Cartfornia Legistative Interta Committees and Thetr Reports 1937-1951. Prepared by the Legislative Auditor, June, 1952. See Reports: 6, 11, 13, 14, 16, $61,71,73,83,97,108,120,129,162,171,194,227,230,238,251,264,265,274,275,277$, $297,298,299,302,309,312,328,342,358,382,397,438,450$. In the 1952 Supp. see Reports: 275, 382, 436. Of particular interest: Sumamary of CaLIforna Statutory Provisions Conferring Quasi-Legislative Functions Upon State Agencies, Assembry Intermar Committee on AdMTINISTRative Regulations (1946), and a supplement to the report published in 1947; Prextminary and Partiat Report and Second Pretimtinary and Partial Report of the Senate Interim Committee on Administrative RegulaTIONS (1953).

\section{Articles}

Kleps, Ralph N. The California Administrative Procedure Act (1947), 22 CALIF. S.B.J. 391 (1947).

Kleps, Ralph N. What Safeguards Should the California Legislature Provide for Administrative Rule Making, 22 Los Awgeiss BaR Bull. 201 (1947).

Mr. Kleps wrote the chapter on Administrative Law in the first Survey of Catarorna Law 1948-1949 (Univ. of Santa Clara 1949); and Mr. John Clarkson, presently Chief of the Division, prepared comparable chapters in the succeeding five volumes. $C f$. the legislative summaries in 27 So. CatIF. L. Rev. 73 (1953); 23 So. Catrf. L. Rev. 2 (1949); 21 So. CaIIF. L. Rev. 21 (1947); 15 Sg. Caxir. L. Rev. 214 (1942).

Kleps, Ralpl N. California's Approach to the Improvement of Administrative Procedure, 32 CAIIF. L. REv. 416 (1944).

First Report: Committee on Administrative Agencies Sirvey, 19 CALIF. S.B.J. 128 (1944).

Judicial Conncil of California Administrative Agency Survey, 19 CaIIF. S.B.J. (Supp. 1944).

Moore, E. D. Judicial Council's Adninistrative Agencies Survey and Proposed Act, 20 Los ANGeles BAR BULL. 122 (1944).

Pfiffner, John M. The Role of the Lawyer in Public Administration, 20 So. CalIF. L. REv, 37 (1946).

Cook, Thomas I. Law, Arbitrariness and Ethics, 30 CaIrF. L. Rev. 151 (1942).

McGowen, John D. The Battle of the Processes, 28 CaxIF. L. Rev. 277, 288 (1940).

Radin, Max. The Courts and Administrative Agencies, 23 CALIF. L. REv. 469 (1935).

\section{Historical Background}

Munro, William B. Our Vanishing Government of Laws, 31 CALIF. L. REv. 49 (1942).

Dimock, Marshall E. The Prospect for Adninistrative Tribunals, 20 Carm. L. Rev. 162 (1932). Vimogradoff, Paul. Some Problems of Public Law, 12 CaLIF. L. Rev. 443 (1924).

Review of Recent Cases for Quarter Ending Dec., 1919, 8 CaLIF. L. REv. 95, 98 (1920). For Quarter Ending Aug., 1919, 7 CaIIF. L. REv. 442 (1919).

\section{DEIEGATION}

Constitutionality of state statute authorizing administrative board to set minimun prices for dry cleaning industry (State Board of Dry Cleaners v. Thrift-D-Lux Cleaners), 42 CaLrF. L. REv. 172 (1954); 29 N.Y.U.L. REv. 747 (1954); 1 U.C.L.A.L. REv. 100 (1953). 
The void for vagueness rule in California, 41 CALIF. L. REv. 523 (1953).

Constitutionality of nonjudicial confinement, 3 STAN. L. REv. 109 (1950).

State, church and child-statutory provisions for school permit, 1 STAN. L. REv. 316 (1949).

Delegation of legislative power to state-wide administrative agencies-primary standards in school district reorganization statutes (comment on a Kansas case), 21 So. Carm. I. REv. 264 (1948).

California Agricultural Prorate Act of 1933 (Agricultural Prorate Comm'n v. Superior Court), 25 CaIIF. L. REv. 493 (1937).

Delegation of legislative power, 24 CAIIF. L. REv. 184 (1936).

Delegation of legislative power to administrative officers (Bank of Italy v. Johnson), 15 CAur. L. REv. 408 (1927).

Delegation of legislative power; regulation of sale of poisons (Ex parte Potter), 1 Carm. L. Rev. 371 (1913).

Cf. 25 Ops. CaL. ATT'y Gen. 304 (1955). School Board's authority to impose library fines may not be delegated to student body organization.

PROCEDURE

Articles and Texts

The most recent text is Witrin, B. E. Carifornia Procedure. (3 volumes) (1954).

Rhyne, Charles. Can You Try an Administrative Agency Case as You Do a Case in Court? 40 A.B.A.J. 751 (1954). Cf. A Manual on TrIal Technique in Admintstrative ProCEEDINGs [Federal] (1950), prepared by E. Barrett Prettyman under the auspices of the Junior Bar Section of the Bar Association of the District of Columbia. See also HoRskx, Charles A. The Washington Lawyer (1952).

Prettyman, E. Barrett. Reducing Delay in Administrative Hearings, 39 A.B.A.J. 966 (1953).

Keeffe, Arthur, Landes, William Jr. and Shaad, Robert. Sense and Nonsense About Judicial Notice, 2 Stan. L. Rev. 664 (1950).

Kleps, Ralph N. The Reform of Administrative Procedure in California, 18 STATE GovernarewT 200 (1945).

Kleps, Ralph N. California's Approach to the Improvement of Admintistrative Procedure, 32 CarIF. L. Rev. 416 (1944).

Thelan, Max. Practice and Procedure Before Administrative Tribunals, 16 CALIF. L. REv. 208 (1928).

Notes

Venue: actions against the state, its officers and agencies, 37 CAIrF. L. REv. 102 (1949).

Right to oral argument before an administrative board (Federal Communications Comm'n), 23 So. Calm. L. Rev. 77, 146 (1949).

Section 11517 of Cabifornia Government Code (Hohreiter v. Garrison), 21 So. Carm. L. REv. 182 (1948). Cf. Deciding administrator need not hear, 1948 STAN. INTrA. L. REv. 142.

Enforcement of subpoena of [federal] administrative agency, (Oklahoma Press Pub. Co. v. Walling), 34 CatrT. L. Rev. 428 (1946); 20 So. Carif. L. Rev. 66 (1946).

Adequacy of hearmgs before civil service board, 20 CALTE. S.B.J. 360 (1945).

Manner of pleading judgments, 30 CArñ. L. REv. 482 (1942).

Administrative decisions as res judicata, 29 Calm. L. REv. 741 (1941).

Practice before adininistrative agencies, 29 CArIF. L. REv. 603, 605 (1941).

Notice, hearing and review (Southern Ry. v. Virginia), 8 So. CaIIF. L. Rev. 330 (1935).

EVIDENCE

Newman, Frank C. How Facts Are Handled in Agency Hearings. Syt.tabus on Cartrornia Admanistrative Law. (University of California Extension 1955).

Bancroft, Richard A. Substantial Evidence Rule: Review of Entire Record, 40 CaLm. L. REV. 119 (1952).

Thelan, Max. Practice and Procedure Before Adntinistrative Tribunals, 16 Carir. L. REv. 208, 215 (1928).

Hearsay testimony, consideration by administrative tribunal (IAC), 13 CALTF. L. REv. 384, 394 (1925).

Articles

JUDICIAL REVIEW

The leading article is Kleps, Ralph N. Certiorarified Mandamus: Court Review of California Administrative Decisions 1939-49, 2 STAN. L. REv. 285 (1950); and most of the pre-1950 articles on California's controversy regarding mandamus are cited in bis footnotes. 
tenBroek, Jacobus and Wilson, Richard B. County of Los Angeles v. State Social Welfare Department-A Criticism, 41 CALIF. L. REv. 499 (1953).

Bancroft, Richard A. Substantial Evidence Rule: Review of Entire Record, 40 CaLIF. L. REv. 119 (1952).

Ice, G. Brooks and Ice, Joyce I. Judicial Review of Rulings by California Admintistrative Agencies, 2 Hastratgs InTRa L. Rev. 48 (Spring 1951).

Ward, John F. Requirements for Filing Claims Against Governmental Units in California, 38 CAITF. L. REv. 259 (1950).

Kuchel, Thomas H. Should California Accept Tort Liability?, 25 CaIrr. S.B.J. 146 (1950).

Newman, Frank C. How Courts Interpret Regulations, 35 CAIIF. L. REv. 509 (1947).

Wilson, Emmet H. Consideration of Facts in Constitutional Cases, 17 So. CaIrF. L. Rev. 335 (1944).

McGovney, D. O. Court Review of Administrative Decisions in California; The Pending State Constitutional Amendment (Art. IV, Sec. 1b), 30 CArIF. L. REv. 507 (1942).

McGovney, D. O. The California Chaos in Court Review of the Decisions of State Administrative Agencies, 15 So. CaIrF. L. REv. 391 (1942).

Elhott, Sheldon D. Certiorari and the Local Board, 29 CAITF. L. REv. 586 (1941).

Turrentine, Lowell. Restore Certiorari to Review State-wide Admirristrative Bodies in California, 29 CaIIF. L. REv. 275 (1941).

McGovney, D. O. Administrative Decisions and Court Review Thereof, in California, 29 CaIr. I. REv. 110 (1941).

Bufford, Charles M. Writ of Mandate Held Available for Revieving Administrative Agencies, 16 CAIIF. S.B.J. (II) 306 (1941).

Holbrook, W. Sumner, Jr. Judicial Review of Determinations by County Boards of Equalization, 14 So. CaITr. L. REv. 276 (1941).

Harris, Arterur and Ward, Robert. Administrative Decisions and Judictas Review (University of California Bureau of Public Administration 1941).

Peters, Raymond E. Review of Administrative Board Rulings Limited to Writ of Mandate, 14 CAIIF. S.B.J. (II) 313 (1939).

Radin, Max. The Courts and Administrative Agencies, 23 Carr. L. REv. 469 (1935).

Notes

Noncompliance with the [federal] APA as reversible error: the function of "prejudicial error" and "seasonable objection," 6 SrAN. L. Rev. 693 (1954).

Controversy requirement for declaratory relief (Govt. Code Section 11440), 41 CALIF. L. REv. 341 (1953).

Sovereign Immunity: a proprietary function (Guidi v. State of Calif.), 27 So. Caxr. L. REv. 490 (1953).

Sovereign Immunity: California claims statutes-"Traps for the unwary," 1 U.C.L.A.L.Rev. 201 (1953).

De novo judicial review of state administrative findings, 65 HARv. L. REv. 1217 (1952).

Claim statutes-effect of Government Code section 1981, 23 So. CAIIF. L. REv. 507 (1950).

Constitutionality of nonjudicial confinement (scope of judicial review), 3 Star. L. REv. 109 (1950).

Contempt: scope of review of contempt orders in California, 37 CALrF. L. REv. 301, 302 (1949).

Court misapplies substantial evidence rule in reviewing administrative board decisions (Moran v. Board of Medical Examiners), 22 So. CaIrF. I. REv. 49 (1949); 1 Sraw. L. Rev. 326 (1949).

Judicial notice of the proceedings of an administrative board (Housman v. Board of Medical Examiners), 21 So. CAI.r. L. REv. 267 (1948).

Judicial review of determinations of Corporation and Insurance Commissioners and other state-wide administrative tribunals (Rattray v. Scudder; Transportation BIdg. Co. v. Daugherty), 34 Cas.r. L. Rev. 741 (1946).

Current constitutional decisions of the United States Supreme Court; Necessity of findings by California Legislature (Cheeseboro v. Los Angeles County Flood Control Dist.), 12 So. CaI.T. I. Rev. 447, 451 (1945).

Scope of trial de novo in mandamus proceeding to review decisions of state administrative body (Dare v. Board of Medical Examiners), 31 Cacrf. L. Rev. 436 (1943).

Administrative adjudication in California and its review by the writ of certiorari, 25 CALIF. I. REv. 694 (1937). 
Exhaustion of administrative remedies (Albelleira v. District Court of Appeal), 29 CaLIF. L. Rev. 515 (1941). Cf. 1 Witkin, B. E., Carmfornta Procedure 316, 578 (1954); California's general rule requiring exhaustion of administrative remedies prior to court review, 29 CaLIF. S.B.J. 250 (1954).

Problem of review for administrative boards and bureaus remains unsolved, 15 CAx.rF. S.B.J. (II) 377 (1940).

Judicial review of administrative decisions-scope of review of mandamus (Drummey v. State Board of Funeral Directors), 13 So. CarIF. L. Rev. 500 (1940); 27 CatarF. L. Rev. 738 (1939).

May either a State or Congress vest in an administrative tribunal the conclusive determination of a question of law?, 26 CAITF. L. REv. 683 (1938).

Judicial review of administrative findings of fact, 25 Caldr. L. REv. 315 (1937).

Judicial review of administrative findings on "fundamental" or "jurisdictional" facts, 21 CaLrF. L. REv. 266 (1933).

Injunction of superior court of act authorized by Railroad Commission (Yolo Water \& Power Co. v. Superior Court), 8 CAIIF. L. REv. 180 (1919).

\title{
IICENSING ( $C f$. PROCEDURE)
}

Clarkson, John G. and Newman, Frank C. California Licensing Procedures. Sxulabus oN Calmornia Admmistrattve LAw. (University of California Extension 1955).

Due process in suspension of licenses-strict liability for horse doping (Sandstrom v. Calif. Horse Racing Board), 22 So. CaIJF. L. REV. 461 (1949).

Due process limitation: a matter of form? (Sandstrom v. Calif. Horse Racing Board), 1 STAN. L. Rev. 141 (1948).

Section 11517 of Calif. Government Code (Hohreiter v. Garrison), 21 So. Carsw. L. REv. 182 (1948). Cf. Deciding administrator need not hear, 1948 STAN. INTRA. L. REv. 142.

Sears, Kenneth C. Licenses and Procedural Due Process, Brochure on Administrative LAw. (A.B.A. Section of Judicial Administration, p. 17, 1943).

Wilson, E. H. Court Takes Rap at Medical Board for Revoking License Without Evidence, 14 CaIrE. S.B.J. (II) 345 (1939).

Licenses-power in officials, 4 So. CAtrF. X. Rev. 410 (1931).

Proceedings before administrative commissions: revocation of licenses (Abrams v. Daugherty), 11 CarTF. L. REv. 273 (1923).

Right of state to revoke physician's license, 3 CALTF. L. REv. 55 (1914).

\author{
BOARD OF EQUALIZATION
}

Decistons of the State Board of Equartzatton (1950 to date).

Van Alstyne, Arvo. Equalization as a Prerequisite to Recovery of Taxes on Exempt Property, 1 U.C.L.A. L. REv. 303 (1954).

Pierce, Dixwell L. Some Aspects of Liquor Control in California, 39 CALIF. L. Rev. 82 (1951). The State Board of Equalization and liquor control, 38 CALIF. L. REv. 875 (1950).

Hutchinson, J. Albert. The Alcoholic Beverage Control Administration of the State Board of Equalization, 20 CArIF. S.B.J. 59 (1945).

Conclusiveness of determination of Board of Equalization; constructive fraud (Rancho Santa Margarita v. San Diego County), 21 CauIr. L. Rev. 285 (1933).

\section{DIVISION OF CORPORATTONS}

Ballantine, Henry W. and Steritng, Grahay L. Jr. Calmornia Corporation Laws (1949) [Chap. XXI, Corporate Securities Act].

Loss, Louts. SEcurtTtes Reguxatron (1951) \& Supplement (1955). [pp. 19-44, Type of State Law; pp. 962-82, Civil Liability].

Pearce, Donald A. DO's and DON'Ts of Practice Before the Division of Corporations, CALIfornia Practice Handiook: Organizing and Advising SmaLI Business Enterprises. Chap. 11 (University of California Extension 1954).

Wheat, Francis M. Issuance of Securities Under the California Securities Law, CaLIForNA Practice Handbook: Organizing and Advising Smali Business Enterprises. Chap. 10 (University of California Extension 1954).

Dahlquist, T.W. Regulation and Civil Liability Under California Corporate Sectrities Act, 33 CALIF. L. REv. 343 (1945) ; 34 CALIF. L. Rev. 344, 543, 695 (1946).

Orschel, Albert K. Administrative Protection for Shareholders in California Recapitalizations, 4 Stan. L. Rev. 215 (1952). 
Smith, Herbert A. Hearing Procedure and Practice Before the Division of Corporations, 18 CALrF. S.B.J. 275 (1943).

Ballantine, Henry W. and Sterling, Graham L. Jr. Upsetting Mergers and Consolidations, 27 CaxIr. L. REv. 644 (1939).

Sterling, Graham L. Jr. Amendment to California Corporation Laws, 1937 : Readjusting Stock Structure, 26 CaIIF. L. Rev. 76 (1937).

Power of Commissioner to investigate licensed brokers (Daugherty v. Superior Court), 26 Carif. L. REv. 498 (1938).

Bluce Sky Laws, 87 A.L.R. 42 (1933).

Dalton, John E. The California Corporate Securities Act, 18 CALIF, L. REv. 115, 255, 373 (1929-30).

Benas, Lionel B. The Corporate Securities Act Recent Cases and Amendments, 14 CArTF. L. REv. 101 (1926).

Loose Leaf Reporter: Blue Sky Law Reporter (CCH).

INDUSTRIAT ACCIDENT COMMISSTON

\section{Decisions}

Decisions of the Industrial Accident Commission (1911-1935). Vol. 20 was the last official publication of the Commission's decisions. Since 1936 the decisions of the Commission have been reported in Cammornia Comprensation Cases (Hanna Legal Publications).

Articles

Hanna, Warren L. The Law of Employee Injuries and Workmen's Compensation (Prepared as a guide for attorneys practicing before the California Commission) (2d ed. 1951). Vol. 1 on practice and procedure, Vol. 2 on principles.

Witrin, B. E. Sumprary of Calfrornia LaW Ch. XI (Workmen's Compensation) (6th ed. 1946).

See Workmen's Compensation chapters prepared by Donald Gallaglier in Volume 1, and Edmund J. Tliomas, Jr., in Volumes $2,3,4,5, \& 6$ of the Survey of Cacifornia Law (Univ. of Santa Clara 1948-1954).

Riesenfeld, Stefan A. Contemporary Trends in Compensation for Industrial Accidents Here and Abroad, 42 CAIIF. I. REv. 531 (1954).

Barry, Richard. The Industrial Accident Commission and the Rules of Evidence, 28 CaLIF. S.B.J. 245 (1953).

Bancroft, Richard A. Some Procedural Aspects of the California Workmen's Compensation Law, 40 CaIIF. L. REv. 378 (1952).

Campbell, Douglass A. Jurisdiction of the California IAC, 26 LOs ANGeles BAR BuLd. 363 (1951).

Mattes, Hans A. Unemployment Compensation Disability Benefits in California, 22 CaLrr. S.B.J. 132 (1947).

Hanna, Warren L. Summary of the 1945 Legislation Affecting Workmen's Compensation, Insurance and Safety, 20 CAIIF. S.B.J. 403 (1945).

Campbell, Douglass A. Industrial Accident Commission, 18 CaLIF. S.B.J. 177 (1943).

Campbell, Douglass A. Industrial Health and Workmen's Compensation in California, 14 CALTr. S.B.J. (I) 254 (1939).

Gallagher, Donald. Power of the IAC to Settle Disputes Arising Under Workmen's Compensation Legislation by the Several Acts of Its Members and Deputies, 27 CaIrF. L. REv. 241 (1939).

Trowbridge, Delger. The Functions and Status of Judicial Officers of the IAC, 11 CALIF. S.B.J. 205 (1936).

Allen, E. O. Fixing of Attorney's Fees by the IAC, 7 CAxIF. S.B.J. 234 (1932).

Trowbridge, Delger. Facts About the IAC, 6 CALIF. S.B.J. 140 (1931).

Pillsbury, Warren H. Review of Decisions of Administrative Tribunals-IAC. (Singer v. Industrial Acc. Comm'n), 19 CarrF. L. Rev. 282 (1931).

Pillsbury, Warren H. Applicability of Methods of Trial and Administration Used in Workmen's Compensation Proceedings to Certain Civil Actions, 18 CaLIF. L. REv. 223 (1930).

Pillsbury, Warren H. An Experiment in Simplified Procedures. Proceedings Before the IAC, 3 CaIIF. L. REv. 181 (1915). 
Notes and Reports

Judicial review of California IAC decisions, 40 CArr. L. REv. 119 (1952).

Has the Jensen case been jettisoned?, 2 Sras. L. Rev. 536 (1950).

Legislative medicine for the sick worker, 2 STAN. L. REv. 345 (1950).

The Industrial Accident Commission, 12 CALIF. S.B.J. 19, 40 (1937); 11 CaIIF. S.B.J. (II) 297 (1936).

Is the California IAC a court? (Bankers Indemnity Co. v. Industrial Acc. Comm'n), 24 CarrF. L. REv. 328 (1935).

Jurisdictional boundaries of the IAC, 8 Los ANGeres BAR BuLL. 87 (1932).

Report: Northern Section of Committee on Practice and Procedure Before the IAC, 8 CaLrF. S.B.J. (II) 45 (1953).

Report: Committee on Administrative Agencies and Tribunals, 26 CArr. S.B.J. 214 (1951); 25 CALIF. S.B.J. 314, 315 (1950) ; 16 CaIIF. S.B.J. (II) 32, 36, 53 (1941).

Report: Committee on practice and procedure before the IAC, 9 CAL.F. S.B.J. (II) 72, 76 (1934).

MOTOR VEHICLE

Ehrenzweig, Albert A. "Full Aid" Insurance for the Traffic Victim-A Voluntary Compensation Plan, 43 CaIIT. L. Rev. 1 (1955).

Constitutionality of safety responsibility law (Escobedo v. State of Calif. and Dept. of Motor Vehicles), 39 CALIF. L. REv. 123 (1951). Cf. Revocation of driver's license without hearing, 5 VAND. L. REv. 96 (1951).

Sweet, Hleson. Proposed Commission Plan for Handling Controversies Arising Out of Automobile Accidents, 7 CaLTF. S.B.J. 142 (1932).

Articles

PUBLIC UTHITIES COMOMISSION

Lakusta, Boris H. Practicing Before the Public Utilities Conmission of Califortia, Srutabus on Caltrornia Administrative Law (University of California Extension 1955).

Schwarzer, William W. Enforcing Federal Supremacy: Relief Against Federal-State Regulatory Confiicts, 43 CaIIF. L. REv. 234 (1955).

Lakusta, Boris H. Regulation of Truckers for Hire in California, 41 CALrF. L. REv. 63 (1953).

Taylor, Marvel M. Economic Regulation of Intrastate Air Carriers in Californic, 41 CaLrF. L. REv. 454 (1953)

Rae, Matthew S., Jr. Scope of Judicial Review of the California Public Utilities Commission, Los ANgeies DaIIy Journat (Oct. 4, 1951).

Peppin, Joln C. Municipal Home Rule in California III. [Power of Cities and Counties to Regulate Under Charters], 32 Carm. L. Rev. 341, 372 (1944).

Rowell, Ira. Practice Before the Railroad Commission, 18 Caxm. S.B.J. 364 (1943).

Cameron, Hubert. The California Railroad Commission, 16 Los ANGeles Bar Bult. 208 (1940).

Wheat, Carl I. Practice and Procedure Before the Railroad Commission of Califormia, 15 CaLIr. L. Rev. 445 (1927).

Graybiel, Lloyd E. Review of Recent California Decisionts on Mutricipal Law, 11 CaIrF. L. REv. 73 (1922).

Jones, William C. Is the Regulation of Railroad Crossings a Municipal Affair?, 5 CarIr. L. REv. 292 (1917).

Eshleman, Jobn M. Control of Public Utilities in California, 2 CaIn. L. REv. 104 (1914).

Note: The substance of two articles las been rendered moot by decisions of the Public Utilities Commission and the courts. The two articles are: Wolcott, Theodore E. Does the Jurisdiction of the California Railroad Comnission Extend to Air Transportation?, 33 CAIIF. L. Rev. 114 (1945); and McKeage, Everett C. The California Railroad Commission Has Jurisdiction Over Intrastate Rates and Charges of Air Lines, 33 CarTF. L. Rev. 298 (1945). See Newman, Frank C. Bibliography, Sydxabus on Calmfornta Administrative Law (University of California Extension 1955).

Notes and Reports

Interstate highway barriers and the household goods mover, 5 STAx. L. REv. 306 (1953).

Invasion of management by commission, 5 Sran. L. Rev. 110 (1951).

Railroad operation of trucks, 4 STAN. L. REv. 89 (1951).

Extent of rights under grandfather clause, 30 CALIF. L. REv. 101 (1941). 
Rate order of Commission; deprivation of company of property without due process, 11 So. CAIIF. L. RE7. 265, 282 (1938).

Authorized purposes for issuance of securities, 26 CaLñ. L. REv. 76, 89-90 (1937).

Judicial review, 25 CAIIF. L. REv. 694, 707-09, 711 (1937); 2 CAIIF. L. REv. 225, 227-28 (1914).

Comparison of Railroad Commission with Industrial Accident Commission, 24 CaLIF. L. REv. 328,330 (1936).

State regulation of interstate motor transportation, 21 CALIF. L. REv. 496 (1933); 22 CaLIF. L. REv. 24, 36 (1933).

Respective powers of Railroad Commission and courts-eminent domain, 6 So. CAITF. L. REF. 160 (1933).

Nonenforceability of contract with city fixing public utility rates, 18 CAIrr. L. REv. 427 (1930).

Invalidity of rates for failure to file with Commission, 14 CALIF. L. REv. 340 (1926).

Grade crossings, chartered cities, 14 CAIIF. L. REv. 313-17 (1926).

Control over railroad engaged in both interstate and intrastate commerce, 12 CarrF. L. REV. 221-24 (1924).

Ordering street railway extension to territory where company has no franchise, $12 \mathrm{CALIF}$. L. Rev. 144-46 (1924).

Power of State Water Commission to reject applications for appropriation, 10 CaLIF. L. REv. 428 (1922).

Right to withdraw from business, 9 CaLIF. L. REv. 435 (1921).

Extraterritorial operation of mumicipal plant, 9 CALT. L. REv. 252-55 (1921).

Injunction by superior court against acts authorized by Commission, S CALIF. L. REv. 180-83 (1920); 7 CAITF. L. REv. 442, 445-46 (1919).

Effect of contracts fixing water rates on Commission's powers, 7 CALIF. L. REv. 121-26 (1919).

Condemnation; fixing of compensation; constitutionality, 7 Caxir. L. REv. 68 (1918).

Power to compel construction of branch lines, 5 CALIF. L. REv. 174 (1917).

Valuation of property for condemnation, 4 Carrf. L. REv. 422 (1916).

Regulation of water company, 3 CaIIr. L. REv. 81 (1914).

Cominerce between ports within state, 2 CALIF. L. REV. 231 (1914).

Commission has authority to set minimum charges, 2 CAII. L. REv. 496 (1914).

Ordering physical connection between telephone counpanies, 2 CAIT. L. REv. 225-30; 428-29 (1914).

Power to order extension of water service, 2 CAIIF. L. REv. 426-27 (1914).

Government regulation of railways, 2 CAIIF. L. Rev. 87 (1914).

State and municipal control of public utility franchises, 1 CAxns. L. REv. 176 (1913).

Granting certificates to enter field already served, 1 Carm. L. Rev. 73 (1912). Report of the Conimittee on Administrative Agencies and Tribunals, 16 CALIF. S.B.J. (II) 32,40 (1941).

Report, Northern Section of Committee on Practice and Procedure Before the Railroad Commission, 15 CaITF. L. Rev. 445 (1927).

\section{Decisions}

Digest of Decisions, Cammornia Ratroad Conamission, Vols. 1-29 (covering period 19121927).

OrInions and Orders of the RaIlroad Comomssion, Vols. 1-46. Continued as OfIntons and Orders of the Public Utmitmes Comanssion, Vol. 47 to date.

Public Utmities Reports and Digest [Federal]. Published by Public Utilities Reports, Inc, Washington, D.C.

\section{MTSCELIANEOUS}

California Unemployment Insurance Appeals Board decisions: Benefir Decisions (1943 to date) and cumulative index. Disabirity Decisions (1947 to date). Disabitity Decisions [Disputed Coverage] (1950 to date). TAX Decisions (1943 to date). Mrscellaneous Decisions (1944-1951). See also Index Digest or Selected Disabuity Dectsrons (1952, 1954 \& 1956).

Rurng Decrsions. (See at State Library, Sacramento, Calif.).

Franchise Tax Board Appeat Decisions. (See at State Library, Sacramento, Calif.).

Walker, Herbert V. The Air Pollution Control Hearing Board-Functions and Jurisdictions, 27 So. CaLTF. L. Rev. 399 (1954). 
Building and loan liquidation, California style, 3 StaN. L. Rev. 60 (1950).

Power of building and loan commissioner to use funds of association of which he has taken possession to lite outside counsel, 28 CarTF. L. REv. 653 (1940).

The Central Valley Project and related problems (of water and power), 38 Cartr. L. REv. 547-781 (1950).

Hamlyn, J.J. The Pohle Case [Whether Executive Officer of State Personnel Board, Under Art. XXIV of Calif. Constitution, Has Any Authority Separate and Distinct from State Personnel Board], 11 CaLIF. State Employee No. 2, 19 (1942).

Power of school board to reduce teacher's salary for not attending summer school, 33 CarIF. L. REv. 140 (1945).

Practieal application of milk regulation through administrative agencies, 14 CAITF. S.B.J. (I) 262 (1939).

Regulation of taking fish and game, 2 CAITF. L. REv. 406 (1914).

Duffy, Milton P. California's Food and Drug Laws-With Some Historical Aspects, 10 Food DRug Cosm. L.J. 21 (1955).

Report of the Committee on Administrative Agencies and Tribunals, 16 CaI.T. S.B.J. (II) (1941) at:

43: Department of Education

43: Division of Prison Terms and Paroles

44: Franchise Tax Commissioner

45: Division of Immigration and Housing

45: Division of State Lands

46: Veterans Welfare Board

47: Contractors Licensing Board

Report of the Committee on Administrative Agencies and Tribunals, 18 Carm. S.B.J. (1943) at:

424: Department of Professional and Vocational Standards

427: Contractors State License Board

432: Board of Registration for Civil Engineers

434: State Veterinary Medical Board

436: State Board of Cosmetology

438: State Board of Architecture

442: Board of Medical Examiners

445: State Board of Optometry

446: Board of Funeral Directors and Embalmers

448: Board of Dental Examiners

449: Structural Pest Control Act of California

453: Yacht and Ship Brokers Act

454: California State Board of Pharnacy

456: State Board of Barber Examiners

Loose-leaf services.

State and Locat Tax Service (PH).

UNEMPLOYMANT INSURANCE REPORTER (CCH). 